\title{
Effect of Different Forms of Silicon on Growth of Spring Wheat Cultivated in Organic Farming System
}

\author{
Jolanta Kowalska ${ }^{1}$ (1) · Józef Tyburski ${ }^{2} \cdot$ Magdalena Jakubowska $^{3} \cdot$ Joanna Krzymińska $^{1}$
}

Received: 10 June 2019 / Accepted: 7 February 2020 / Published online: 20 February 2020

(C) The Author(s) 2020

\begin{abstract}
Application of silicon $(\mathrm{Si})$ could greatly boost wheat growth and yield by mitigating abiotic stress, especially drought. Aim The objective of this study was to determine the effect of silicon products in different forms and methods of its application on growth and yield of spring wheat cultivated under organic farming regime.

Methods A field experiment was conducted in the period of 2017-2018 on a research farm. The impact of different methods of application of powder and liquid forms of Si products to soil, leaves and combined methods of application (to soil and leaves) on growth parameters and yielding of spring wheat was evaluated. The treatments consisted of the recommended doses of two $\mathrm{Si}$ products - Adesil and ZumSil at $10 \mathrm{~kg}$ and $0.3 \mathrm{l} / \mathrm{ha}$, respectively. The effect of silicon was assessed by measuring emergence and height of plants, number and weight of ears, as well as the SPAD index and yield.

Results The number of plants emergence (316-321 seedlings per $1 \mathrm{~m}^{2}$ ), the number of spikes and the height of plants were the highest after application of the liquid form of silicon, regardless of the method of application. The yield was statistically higher after the combined and foliar applications of liquid form of silicon (4.97 and 4.84 t/ha, respectively). The powder silicon form was similar effective when was used as the combined application (to soil and leaves) (5.35 t/ ha).

Conclusions Si stimulates growth of wheat enhancing number of ears and plant height, increases yields of organically grown spring wheat, a liquid Si formulation (solution of monosilicic acid) is more effective than a powder Si formulation (diatomaceous earth). Soil and foliar Si application is more effective than soil or foliar application.
\end{abstract}

Keywords Diatomaceous earth $\cdot$ Monosilicic acid $\cdot$ Silicon application $\cdot$ SPAD $\cdot$ Triticum aestivum $\cdot$ Yield

\section{Introduction}

According to Sommer et al. [25] silicon ( $\mathrm{Si}$ ) is ranked as the second most abundant element in the Earth. All plants grown in soil contain it in their tissues, but the role of Si in plants was, and partly still is, not very clear. Numerous studies devoted to

Magdalena Jakubowska

Jolanta Kowalska

J.Kowalska@iorpib.poznan.pl

1 Department of Biological Pest Control and Organic Agriculture, Institute of Plant Protection- NRI, 60-318 Poznan, Poland

2 Department of Agrosystems, University of Warmia and Mazury in Olsztyn, 10-719 Olsztyn, Poland

3 Department of Agrophages' Forecasting Methods, Institute of Plant Protection- NRI, 60-318 Poznan, Poland
Si potential have been made. They have demonstrated Si positive influence on the improvement of crop growth and yielding. In general terms, the more stressful growing conditions (e.g. drought, high heavy metals content, soil salinity, pathogen and/or insect infestation), the higher chance to obtain positive results of Si application [3, 18]. There might be different mechanisms of Si plant protective activity. It can enhance natural enemy attraction and/or induce plant defence probably via changing volatile profile produced by plants being attacked by insects [15]. It has also been found that $\mathrm{Si}$ displays similarities to plants stress hormones such as jasmonate and salicylain in its ability to modulate of induced resistance. In this way plants gain the ability to respond earlier and more efficiently to a pathogen or insect attack $[13,15]$. Application of soluble form of Si can reduce severity of plant diseases [20, 22]. According to Griffin et al. [9] Si reduces slug feeding on wheat seedlings. An increased Si content in 
leaves might be a method of crop protection against slugs and snails.

Although not an essential plant nutrient, Si often plays a beneficial role. Yield increase in response to its application was found frequently in Si-accumulating crops, as rice and sugarcane. The mechanism of yield growth is based on increased plant tolerance to many biotic and abiotic stresses. Biotic stresses include plant pathogen and insect pests, abiotic ones - draught, salinity and metal toxicity [11]. Another advantage of Si application might be increased soil respiration of soils deficient in phosphorous. $\mathrm{Si}$ is one of the main components regulating $\mathrm{P}$ mobilization in Artic soils. It is assumed that Si may play an important role for management of $\mathrm{P}$ availability in all types of soils [21].

Silicon included in fertilizers or/and in bio-stimulators might be used and be strongly efficient in organic and sustainable crop production because it is critical to plant defense against pests and diseases as well as environmental stresses. It appears to be necessary for an increase yield and sustain crop productivity to improve Si management. The literature on silicon and its influence on plants shows that this element stimulates plant growth and development and reduces the threat of pathogen and pest infestation because silicon is needed by plants to grow strong cell walls [20]. In most cases however, it is uncertain whether growth stimulation is attributable to a nutritional effect or to the alleviation of biotic or abiotic stresses by Si acting at physiological, biochemical, and molecular levels through metabolism regulation and gene expression alternation [16]. Study of Ming et al. [19] suggested that application of $\mathrm{Si}$ increased water and osmotic potential in roots and leaves and that water stress could be partially alleviated by addition of $\mathrm{Si}$. According to another study $\mathrm{Si}$ mediated changes are results in a new balance of endogenous hormones enhancing the tolerance of the wheat plants against drought stress (Xu et al. [26]. Potential of silicon should be used in organic crops where some problems occur with nutrition of plants and with pests because of strict rules for fertilizers and protection products allowed to use in organic farming. In this system of cultivation water stress is especially harder to tolerate by plants less nourished.

The formulations of silicon available on the market differ in their mechanisms of activity, technological purpose and origin [1]. All plants need some silicon in the form of monosilicic acid in the soil to thrive. All soils have a lot of silicon present, sandy soils more than clays, but most is in the form of silicon dioxide which is insoluble and unavailable for plants. Many soils do not have enough monosilicic acid to match the plants requirement. The possibility of developing an effective strategy for supplying silicon in various forms is especially needed for the organic production system. Minimizing the adverse effects of abiotic and biotic stresses on specific crop species through the appropriate use of silicon in their cultivation is an environmentally safe alternative to chemical crop production agents.

The objective of this study was to determine the effect of silicon products in different forms and methods of its application on growth and yield of spring wheat cultivated under organic farming regime.

\section{Materials and Methods}

\subsection{Field Experiment}

Field experiments under organic regime were carried in the years of 2017-2018 in an experimental field station in Winna Góra $(52.2 \mathrm{~N} ; 17.4 \mathrm{E})$ of the Institute of Plant Protection National Research Institute in Poland. The nutrient status of soil was classified medium to very high. Soil content of available elements, organic matter and $\mathrm{pH}$ are shown in Table 1.

The representative soil samples were obtained from the ploughing level $(0-20 \mathrm{~cm})$ by aid of Egner's cane. The taken material was dried to the state of air dry, ground and sieved by a sieve of $1 \mathrm{~mm}$ mesh. Such prepared samples of soil underwent a chemical analysis and there were measured:

- potentiometically $\mathrm{pH}$ in suspension of $1 \mathrm{~mol} \mathrm{KCl} \cdot \mathrm{dcm}^{-3}$ solution,

- content of form of P \& K were determined by method of Egner-Riehm,

- content of assimilable Mg by Schachtschabel's method,

- content of organic carbon by Turin's method,

The experiment was performed using Arabella cultivar of spring wheat grown in a crop rotation after potato. Soil devoid of silicon application was used as a control treatment. The cultivation method included sowing in standard row spacing $(12 \mathrm{~cm})$, with standard sowing ratio of $200 \mathrm{~kg}$ of grain per hectare, and mechanical weed control. No mineral fertilizers were used.

Table 1 Selected soil chemical properties, Winna Góra 2017 and 2018

\begin{tabular}{llllll}
\hline Properties & 2017 & & & 2018 & \\
\cline { 2 - 3 } \cline { 5 - 6 } \cline { 5 - 6 } & Data & Rating & & Data & Rating \\
\hline $\mathrm{pH}_{\mathrm{KCl}}$ & 6.2 & slightly acid & & 6.0 & slightly acid \\
$\mathrm{C}_{\text {org }}, \%$ & 0.79 & low & & 0.72 & low \\
Organic matter, \% & 1.36 & low & & 1.24 & low \\
$\mathrm{P}, \mathrm{mg} \cdot \mathrm{kg}^{-1}$ & 156 & high & & 104 & medium \\
$\mathrm{K}, \mathrm{mg} \cdot \mathrm{kg}^{-1}$ & 193 & high & & 125 & medium \\
$\mathrm{Mg}, \mathrm{mg} \cdot \mathrm{kg}^{-1}$ & 83 & very high & 61 & high \\
\hline
\end{tabular}


Table 2 Average air temperatures, relative humidity (RH) and rainfall during spring wheat vegetation, data for 2017 and 2018

\begin{tabular}{lllllll}
\hline & $\begin{array}{l}2017 \\
\text { Temp }\left[{ }^{0} \mathrm{C}\right]\end{array}$ & 2018 & $\begin{array}{l}2017 \\
\text { RH [\%] }\end{array}$ & 2018 & $\begin{array}{l}2017 \\
\text { Rainfall }[\mathrm{mm}]\end{array}$ \\
\hline April & 7.9 & 13.7 & 77.2 & 70.2 & 38.2 & 24.5 \\
May & 14.3 & 17.5 & 74.2 & 66.6 & 64.3 & 22.4 \\
June & 18.2 & 18.8 & 72.4 & 68.7 & 51.0 & 56.0 \\
July & 18.6 & 21.0 & 78.5 & 72.0 & 77.1 & 95.1 \\
\hline
\end{tabular}

\subsection{Weather Data during Tests}

The climate conditions were fluctuating due to changing seasons from April until mid-July different conditions of weather were noted. The average values are presented in Table 2.

\subsection{Experiment Design}

The experiment was set as a big block area where eight observation points have been designated across the whole area $\left(100 \mathrm{~m}^{2}\right)$, one silicon product was used in one block area. Two silicon products were used - AdeSil ${ }^{\circledR}$ as powder formulation at the dose of $10 \mathrm{~kg} /$ ha and ZumiSil ${ }^{\mathrm{TM}}$ as liquid trade formulation at the dose of $0.3 \mathrm{l} / \mathrm{ha}$. These products are considered anti-stress products. ZumSil is a $24 \%$ solution of monosilicic acid. AdeSil is amorphous diatomaceous earth form and comes in powder formulation such as a flour texture. The powder form of silicon was applied to soil and mixed before sowing, in later stage of vegetation it was used as a water solution by foliar spraying. This diatomaceous earth originates from fresh water and contains $89 \%-95 \%$ of amorphous silica $\mathrm{SiO}_{2}$.

In the study three different methods of application were used. Each silicon product was separately applied on a big block area: (1) only one application before sowing, directly to the soil, (2) three foliar applications, (3) combined soil and foliar application. Thus, three combinations for each silicon product were performed. The first foliar spraying was made at BBCH 23-25, the next one was carried out at the stem elongation phase the last application was made at $\mathrm{BBCH} 61$ (start of blooming). During the field experiment different parameters as indicator of growth plants were assessed - i) emergence, ii) plant height in different development stages, iii) SPAD values in different development stages, iv) number of spikes and yield. The number of emergences per $\mathrm{m}^{2}$ was evaluated at BBCH 32 on each (out of eight) point of evaluation designated on a big block area; the height of plants was evaluated at $\mathrm{BBCH} 21, \mathrm{BBCH} 39$ and $\mathrm{BBCH} 75$ as measures of 50 plants collected from each designated point of evaluation. The SPAD chlorophyll index was measured four times at $\mathrm{BBCH} 31$, $\mathrm{BBCH} 32, \mathrm{BBCH} 51$ and $\mathrm{BBCH} 75$ in the same point of evaluation using the SPAD-502 chlorophyll meter on 10 plants (Minolta Camera Co., Japan). The number of spikes per one square meter was evaluated at $\mathrm{BBCH} 75$ as a mean number of spikes on 8 designated points across a whole big block area.

\subsection{Statistical Analysis}

The results were analyzed statistically by two-way (silicon product and method of application) ANOVA. The significance of differences between the mean values was verified by Tukey's test at the level $p \leq 0.05$.

\section{Results}

Generally, it was confirmed that treatments with silicon had a positive effect on growth and yielding of spring wheat. The highest number of emergence was obtained on the area where ZumSil (liquid form) was applied, regardless of method of application. However, the best effect was obtained after application of a liquid form before sowing (321 seedlings per 1 square meter) directly to the soil and in combined (soil plus foliar) application (316 seedlings) (Fig. 1).

The values of SPAD obtained after application of Si were often higher compared to the values of SPAD from untreated plants however differences did not vary significantly (Table 3). Furthermore, the differences in this parameter were observed depending in the time of measurement, as its values were the highest (at range of 44.3-48.5) at the earring formation stage, however these differences were not statistically confirmed (Table 3.)

The assessment of the height of wheat plants were made at BBCH 21 and BBCH 39. The treated plants were higher (in the range between $51.0-51.6 \mathrm{~cm}$ ) compared to the untreated $(43.9 \mathrm{~cm})$, due to the application of liquid silicon regardless of methods of its application (Table 4). A similar effect was observed only when amorphous diatomaceous earth was applied as combined soil and foliar application $(49.7 \mathrm{~cm})$ (Table 4).

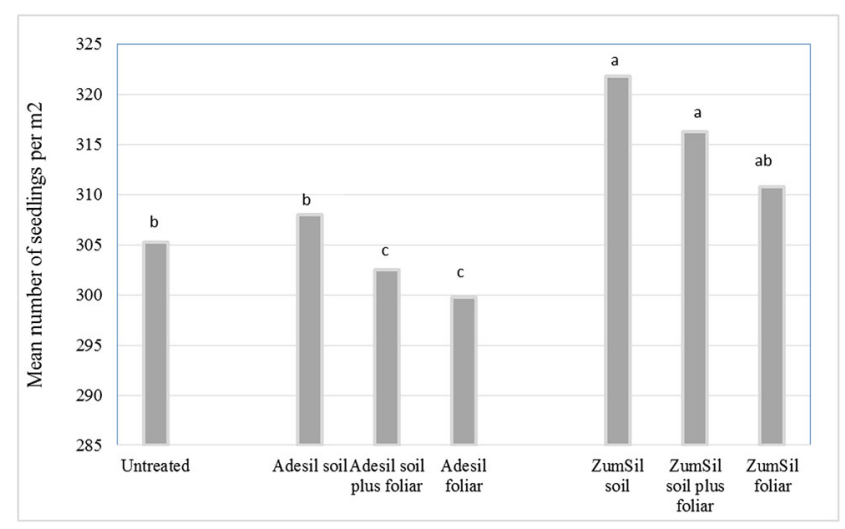

Fig. 1 Mean number of seedlings per $1 \mathrm{~m}^{2}$ at stage $\mathrm{BBCH} 32$ 
Table 3 Effect of different forms, methods and time of application of silicon on SPAD values, means for 2017-2018

\begin{tabular}{lllll}
\hline & BBCH 31 & BBCH 32 & BBCH 51 ears formation & $\begin{array}{l}\text { BBCH 75 milk } \\
\text { grain maturity }\end{array}$ \\
Si forms and methods of application & & & & 43.4 \\
\hline Untreated & 32.4 & 34.6 & 44.3 & 46.3 \\
Treated with Si powder form & & & & 45.2 \\
Adesil, soil application & 32.5 & 36.4 & 47.2 & 44.9 \\
Adesil, soil plus foliar application & 33.8 & 37.5 & 47.9 & 43.9 \\
Adesil, foliar application & 32.9 & 35.1 & 46.5 & 40.6 \\
Treated with Si liquid form & & & & 33.0 \\
ZumSil, soil application & 33.1 & 33.9 & 45.5 & \\
ZumSil, soil plus foliar application & 31.9 & 34.2 & 48.5 & 46.3 \\
ZumSil, foliar application & 32.5 & 34.4 & 4.5 & \\
\hline
\end{tabular}

Adesil - amorphous diatomaceous earth form, ZumSil - solution of monosilicic acid
Later development of plants confirmed beneficial effect of silicon on the height of plants. The best results were noted in a combination where liquid silicon was applied, regardless of the mode of its application (plants height was in the range of $66.7-66.1 \mathrm{~cm}$ ) (Fig. 2).

The untreated plants were lower $(60.3 \mathrm{~cm})$ but the lowest plants were observed in combination where powder form of silicon was applied. This effect is probably related to drought and limitations of water in the soil, so powder formulation was not available for plants to a sufficient degree.

Similarly, like in the case of the height of plants, a high mean number of spikes was noted after application of liquid form of silicon (at the range of $453.7-478.5 / \mathrm{m}^{2}$ ), regardless of method of application (Table 5).

Also a higher mean number of spikes was observed after application of powder form of silicon, but only applied as combined soil and foliar treatments $\left(464.7 / \mathrm{m}^{2}\right)$ and on area where powder formulation was applied only to the soil (393.2/ $\left.\mathrm{m}^{2}\right)$ or as foliar $\left(431.7 / \mathrm{m}^{2}\right)$ the results were lower. The differences in this parameter were significantly important. The

Table 4 Height of plants in relation to $\mathrm{Si}$ forms at two development stages of plants, mean for 2017-2018

\begin{tabular}{lll}
\hline $\begin{array}{l}\text { Si forms and methods } \\
\text { of application }\end{array}$ & $\begin{array}{l}\text { BBCH 21 } \\
\text { beginning } \\
\text { of tillering [cm] }\end{array}$ & $\begin{array}{l}\text { BBCH 39 flag } \\
\text { leaf [cm] }\end{array}$ \\
\hline $\begin{array}{l}\text { Untreated } \\
\begin{array}{l}\text { Treated with Si powder form } \\
\text { Adesil, soil application }\end{array}\end{array}$ & 13.6 & $43.9 \mathrm{c}$ \\
$\begin{array}{l}\text { Adesil, soil plus foliar application } \\
\text { Adesil, foliar application }\end{array}$ & 14.4 & $49.3 \mathrm{~b}$ \\
$\begin{array}{l}\text { Treated with Si liquid form } \\
\text { ZumSil, soil application }\end{array}$ & 14.0 & $49.7 \mathrm{ab}$ \\
ZumSil, soil plus foliar application & 14.3 & $49.0 \mathrm{~b}$ \\
ZumSil, foliar application & 13.9 & $51.0 \mathrm{a}$ \\
\hline
\end{tabular}

a, b, c- homogenous groups at $P \leq 0.05$ number of spikes and its weight (Tables 5 and 6 ) were related to yielding. The best effect on the development of spikes was noted after a combined (to soil and leaves) application of liquid form of silicon - the spikes had the biggest weight $(1.87 \mathrm{~g})$ and the length $(5.94 \mathrm{~cm})$ (Table 6). The liquid form of silicon was the most effective for plants and yielding.

In the field experiment yields were statistically the highest after using liquid formulation of $\mathrm{Si}$, on combined mode of its application (4.97 t/ ha) (Table 7). In the case of silicon powder form based on diatomaceous earth combined soil and foliar application had the biggest positive influence on the yield (5.35 t/ ha).

\section{Discussion}

As silicon is not harmful, not corrosive and not polluting to plants (even when present in excess), its application is regarded as an ecologically and environmentally friendly method to stimulate plant growth, mitigate many biotic and

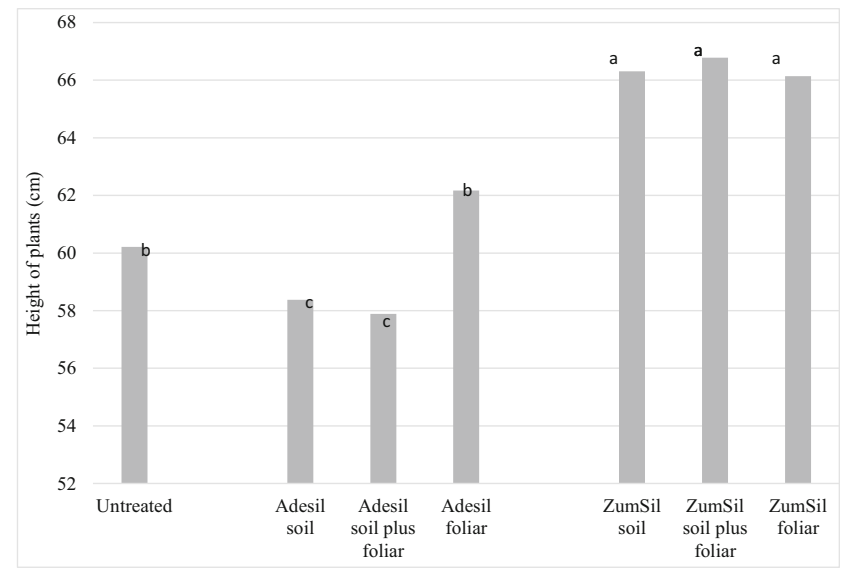

Fig. 2 Effect of different Si forms and methods of application on height of plants at $\mathrm{BBCH} 75$. Unfertilized soil was used as a control treatment. Values marked with the same letter are not significantly different at $P \leq$ 0.05 
Table 5 Effect of different forms and methods of application of silicon on mean number of spikes as a parameter of yielding, means for 20172018

\begin{tabular}{ll}
\hline Si forms and methods of application & $\begin{array}{l}\text { Mean number of spikes } \\
\text { per } 1 \mathrm{~m}^{-2} \text { at BBCH } 75\end{array}$ \\
\hline Untreated & $374.0 \mathrm{c}$ \\
$\begin{array}{l}\text { Treated with Si powder form } \\
\text { Adesil, soil application }\end{array}$ & $393.2 \mathrm{bc}$ \\
Adesil, soil plus foliar application & $464.7 \mathrm{a}$ \\
Adesil, foliar application & $431.7 \mathrm{bd}$ \\
Treated with Si liquid form & \\
ZumSil, soil application & $453.7 \mathrm{a}$ \\
ZumSil, soil plus foliar application & $478.5 \mathrm{a}$ \\
ZumSil, foliar application & $462.0 \mathrm{a}$ \\
\hline
\end{tabular}

a, b, c, d-homogenous groups at $P \leq 0.05$

abiotic stresses in plants, and increase plant resistance to multiple stresses. There are researchers who predict that Si application will become a sustainable strategy to enhance crop growth and mitigate biotic and abiotic stresses in the future [4]. It is assumed that the mechanism for $\mathrm{Si}$ induced resistance to diseases is of dual nature. Si acts as a physical barrier, and $\mathrm{Si}$ implicated in soluble form acts as a modulator of host resistance to pathogens. According to Liang et al. [17] both modes of actions can be unified as a single hypothesis. The first way of action is the result of deposition of double layer of Si beneath the cuticle mechanically impeding fungi penetration and slowing down an infection process. Si also alters directly or indirectly gene expression. It either associates with plant genes and modifies their configuration or acts on the signal transduction pathway activated by infection, and as a result acts as a natural activator of plant disease resistance. Host cell structure, metabolism and functions are modified and signal pathways required for host invasion are interfered with. It prevents the invading fungus from inhibiting the plant defense. Additionally, the intercellular space becomes a hostile environment for a fungal pathogen - proteases and other plant molecules adversely affecting fungus development are released. Other study suggests that exogenous $\mathrm{Si}$ improves the plant growth by modulating the nutrient $(\mathrm{Na}, \mathrm{Mg}$ and $\mathrm{Si}$ ) uptake and phytohormone levels and alleviate plant stress levels $[7,26]$. It was found that $\mathrm{Si}$ application suppressed among others leaf and neck blast, brown spot, leaf scald, grain coloration, stem rot, bacterial leaf blight, root rot nematode infection in rice and still more kinds ailments in many other crops [18]. In wheat powdery mildew is suppressed by $\mathrm{Si}$ nutrition and among insect pests the green bug (Scizaphis graminum) $[5,6]$. and the red flour beetle (Tribotium castaneumare) [23]. The influence of silicon on crops such as vegetables, fruit trees and shrubs, rape, wheat, potato, corn and meadow plants has been investigated also in Poland [8]. A positive effect of silicon application of spring wheat in organic farming was generally confirmed in this study.

The SPAD chlorophyll meter is useful for a quick analysis of chlorophyll and nitrogen status of crops, while it has not been established how strongly the meter readings are correlated with fertilization and different fertilizer management options. Our results indicated that silicon application had rather a positive influence on development and yielding of spring wheat. This crop has very limited research on silicon, especially in organic farming system. In present work, the SPAD index was different depending on the time of measurement and the stage of development, as its values were the highest at the earring formation. This effect is similar with other research conclusions obtained by Radkowski and Radkowska, who noted the highest SPAD at the flowering stage of timothy grass after silicate fertilizer [20]. Our results on SPAD values did not confirm statistically important differences in relation to silicon application, only positive tendency, Silva et al. [24] also confirmed that silicon has a beneficial effect with regard to chlorophyll, however there were used other methods such as analytical methods of assessment of chlorophyll. Ahmad et al. [1] who investigated the role of silicon in fertilization of wheat (T. aestivum) in different soil humidity conditions,
Table 6 Length and weight of spikes in relation to application of silicon, means for 2017-2018

\begin{tabular}{lll}
\hline Si forms and methods of application & Length of the spike $[\mathrm{cm}]$ & Weight of the spike $[\mathrm{g}]$ \\
\hline Untreated & $5.49 \mathrm{c}$ & $1.71 \mathrm{~b}$ \\
Treated with Si powder form & & \\
Adesil, soil application & $5.38 \mathrm{c}$ & $1.61 \mathrm{bc}$ \\
Adesil, soil plus foliar application & $5.54 \mathrm{bc}$ & $1.64 \mathrm{bc}$ \\
Adesil, foliar application & $5.58 \mathrm{bc}$ & $1.58 \mathrm{c}$ \\
Treated with Si liquid form & & \\
ZumSil, soil application & $5.44 \mathrm{bc}$ & $1.66 \mathrm{bc}$ \\
ZumSil, soil plus foliar application & $5.94 \mathrm{a}$ & $1.87 \mathrm{a}$ \\
ZumSil, foliar application & $5.25 \mathrm{c}$ & $1.70 \mathrm{~b}$ \\
\hline
\end{tabular}

a, b, c- homogenous groups at $P \leq 0.05$ 
Table 7 Yield of spring wheat and grain moisture in relations to silicon application, means for 2017-2018

\begin{tabular}{lccc}
\hline Forms and methods of application & $\begin{array}{l}\text { Weight of grain } \\
\text { per plot } / 6 \mathrm{~m}^{2}[\mathrm{~kg}]\end{array}$ & Moisture of grain [\%] & Yield [t per ha] \\
\hline Untreated & 7.72 & 13.5 & $3.88 \mathrm{c}$ \\
Treated with Si powder form & & & $4.75 \mathrm{~b}$ \\
Adesil, soil application & 9.46 & 13.5 & $5.35 \mathrm{a}$ \\
Adesil, soil plus foliar application & 10.64 & 13.5 & $4.25 \mathrm{c}$ \\
Adesil, foliar application & 8.44 & 13.3 & $4.49 \mathrm{bc}$ \\
Treated with Si liquid form & & & $4.97 \mathrm{a}$ \\
ZumSil, soil application & 8.92 & 13.4 & $4.84 \mathrm{ab}$ \\
ZumSil, soil plus foliar application & 9.92 & 13.8 & 13.6 \\
ZumSil, foliar application & 9.64 & & \\
\hline
\end{tabular}

a, b, c- homogenous groups at $P \leq 0.05$ reported that silicon application considerably improved plant biomass, height and ear weight. Also tests presented by [10] confirmed a beneficial effect of root and foliar application of silicon to wheat plants. The presented results also confirm theirs findings, however the research conducted by Segalin et al. [22] revealed that foliar application of silicon did not affect yield nor physiological quality of wheat seeds of different cultivars. In other crops beneficial effect of silicon also was indicated, the obtained results by Artyszak et al. [2] demonstrated that the use of the environmentally safe calcium and silicon foliar fertilizer (Herbagreen basic) is advantageous for the sugar beet production. The divergent test results indicate the need to continue the research. It may be presumed that the plants well tolerating biotic or abiotic stress will be less responsive to silicon.

The combined - foliar and soil applications of liquid form of silicon - were the most effective for growth of spring wheat. The yield response to Si may be also related to an improved uptake of this nutrient [12] and the methods application. This conclusion is also in line with ours. The application of silicon can be component of integrated plant management and be applied with other plant protection practices, especially in organic farming where only limited plant production means are allowed. Fertilization of organic crops is a key element contributing to the health of plants, through the appropriate strategy of providing key ingredients for a crop can indirectly limit even the symptoms of the disease, as was demonstrated by the study Kowalska and Drożdżyński [14] on reducing the symptoms of late blight potato fertilized with potassium.

\section{Conclusions}

The results of the field experiment confirmed a beneficial effect of silicon fertilizers for organically cultivated spring wheat. During the study, the relative chlorophyll content, expressed as the leaf greenness index (SPAD) was found to increase up to earring formation. The plants treated by silicon were better developed which was expressed by a higher number of emergence, the height of plants and density of spikes and yield. The most efficient form of silicon product was a liquid formulation with solution of monosilicic acid, while diatomaceous earth was less effective and only in combined application achieved similar effects such as liquid silicon. No differences between the effectiveness of liquid form of silicon in relation to the methods of application were noted, this indicates that there is the possibility of limiting the number of treatments and manual physical work, although it should be emphasized that the best effect was achieved after combined (soil and foliar) treatments.

Acknowledgements Scientific publication financed by the Ministry of Science and Higher Education of the Republic of Poland. Thanks to Perma-Guard ${ }^{\mathrm{TM}}$ for delivering the silicon products.

\section{Compliance with Ethical Standards}

Disclosure None of the authors has any financial or other relationships that could lead to a conflict of interest.

Open Access This article is licensed under a Creative Commons Attribution 4.0 International License, which permits use, sharing, adaptation, distribution and reproduction in any medium or format, as long as you give appropriate credit to the original author(s) and the source, provide a link to the Creative Commons licence, and indicate if changes were made. The images or other third party material in this article are included in the article's Creative Commons licence, unless indicated otherwise in a credit line to the material. If material is not included in the article's Creative Commons licence and your intended use is not permitted by statutory regulation or exceeds the permitted use, you will need to obtain permission directly from the copyright holder. To view a copy of this licence, visit http://creativecommons.org/licenses/by/4.0/.

\section{References}

1. Ahmad F, Aziz T, Maqsood MA, Tahir MA, Kanwal S (2007) Effect of silicon application on wheat (Triticum aestivum L.) growth under water deficiency stress. Emir J Food Agric 19:1-7 
2. Artyszak A, Gozdowski D, Kucińska K (2014) The effect of foliar fertilization with marine calcitein sugar beet. Plant Soil Environ 60(9):413-417

3. Epstein E (2009) Silicon: its manifold roles in plants. Ann Appl Biol 155(2):155-160. https://doi.org/10.1111/J.1744-7348.2009. 00343

4. Etesami H, Ryong Jeong B (2018) Review and future prospects on the action mechanisms in alleviating biotic and abiotic stresses in plants. Ecotoxicol Environ Saf 147:881-896

5. Fauteux F, Chain F, Belzile F, Menzies JG, Belanger RR (2006) The protective role of silicon in the Arabidopsis-powdery mildew pathosystem. Proc Natl Acad Sci USA 103(46):17554-17559. https://doi.org/10.1073/Pnas.0606330103

6. Gomes FB, De Moraes JC, Dos Santos CD, Goussain MM (2005) Resistance induction in wheat plants by silicon and aphids. Sci Agric 62(6):547-551. https://doi.org/10.1590/S0103-90162005000600006

7. Gong HJ, Chen KM, Zhao ZG, Chen GC, Zhou WJ (2008) Effects of silicon on defense of wheat against oxidative stress under drought at different developmental stages. Biol Plant 52(3):592596

8. Gorecki RS, Danielski-Busch W (2009) Effect of silicate fertilizers on yielding of greenhouse cucumber (Cucumis sativus L.) in container culitivation. J Elementol 14(1):71-77

9. Griffin M, Hogan B, Schmidt O (2015) Silicon reduces slug feeding on wheat seedlings. J Pest Sci 88(1):17-24. https://doi.org/10.1007/ S10340-014-0579-1

10. Guevel MH, Menzies JG, Belanger RR (2007) Effect of root and foliar applications of soluble silicon on powdery mildew control and growth of wheat plants. Eur J Plant Pathol 119(4):429-436. https://doi.org/10.1007/S10658-007-9181-1

11. Haynes R (2014) A contemporary overview of silicon availability in agricultural soils. J Plant Nutr Soil Sci 177(6):831-844. https:// doi.org/10.1002/Jpln.201400202

12. Huang X, Zhang Z, Ke Y, Xiao C, Peng Z, Wu L, Zhong S (1997) Effects of silicate fertilizer on nutrition of leaves, yield and sugar of sugarcanes. Trop Subtrop Soil Sci 6:242-246

13. Keeping MG, Reynolds OL (2009) Silicon in agriculture: new insights, new significance and growing application. Ann Appl Biol 155(2):153-154. https://doi.org/10.1111/J.1744-7348.2009.00358

14. Kowalska J, Drożdżyński D (2018) Effects of potassium fertilization on late potato blight and yield - short communication. Plant Protect Sci 54(2):87-91. https://doi.org/10.17221/79/2017-PPS

15. Kvedaras OL, An M, Choi YS, Gurr GM (2010) Silicon enhances natural enemy attraction and biological control through induced plant defences. Bull Entomol Res 100(3):367-371. https://doi.org/ $10.1017 / \mathrm{S} 0007485309990265$
16. Liang YC, Si J, Romheld V (2005) Silicon uptake and transport is an active process in Cucumis Sativus. New Phytol 167(3):797-804. https://doi.org/10.1111/J.1469-8137.2005.01463

17. Liang YC, Nikolic M, Bélanger R, Gong H, Song A (2015) Silicon in agriculture. Dordrecht, Springer. pp. 235. https://doi.org/10. 1007/978-94-017-9978-2. isbn:9789401799782

18. Meena VD, Dotaniya ML, Coumar V, Rajendiran S, Kundu S, Rao AS (2014) A case for silicon fertilization to improve crop yields in tropical soils. Proc Natl Acad Sci India Sect B 84(3):505-518

19. Ming D, Pei Z, Naeem M, Gong H, Weijun Z (2012) Silicon alleviates PEG-induced water-deficit stress in upland Rice seedlings by enhancing osmotic adjustment. J Agron Crop Sci 198(1):14-26. https://doi.org/10.1111/j.1439-037X.2011.00486.x

20. Radkowski A, Radkowska I (2018) Effects of silicate fertilizer on seed yield in timothy-grass (Phleum pratense L.). Ecol Chem Eng $S$ 25(1):169-180. https://doi.org/10.1515/Eces-2018-0012

21. Schaller J, Faucherre S, Joss H, Obs M, Goeckede M, PlanerFriedrich B, Peiffer S, Gilfedder B, Elberling B (2019) Silicon increases the phosphorus availability of arctic soils. Sci Rep 9:111. https://doi.org/10.1038/S41598-018-37104-6

22. Segalin SR, Huth C, Rosa TDA, Pahins DB, Mertz LM, Nunes UR, Martin TN (2013) Foliar application of silicon and the effect on wheat seed yield and quality. J Seed Sci 35(1):86-91

23. Sétamou M, Schulthess F, Bosque-Pérez NA, Thomas-Odjo A (1993) Effect of plant nitrogen and silica on the bionomics of Sesamia Calamistis (Lepidoptera: Noctuidae). Bull Entomol Res 83(3):405-411

24. Silva ON, Lobato AKS, Ávila FW, Costa RLC, Oliveira Neto CF, Santos Filho BG, Martins Filho AM, Lemos R, Pinho JM, Medeiros MBCL, Cardoso MS, Andrade IP (2012) Siliconinduced increase in chlorophyll is modulated by the leaf water potential in two water-deficient tomato cultivars. Plant Soil Environ 58(11):481-486

25. Sommer M, Kaczorek D, Kuzyakov Y, Breuer J (2006) Silicon pools and fluxes in soils and landscapes - a review. J Plant Nutr Soil Sci 169(3):310-329. https://doi.org/10.1002/Jpln.200521981

26. Xu L, Islam F, Ali B, Pei Z, Li J, Ghani MA, Zhou W (2017) Silicon and water-deficit stress differentially modulate physiology and ultrastructure in wheat (Triticum aestivum L.). 3 Biotech 7(4):273. https://doi.org/10.1007/s13205-017-0904-5

Publisher's Note Springer Nature remains neutral with regard to jurisdictional claims in published maps and institutional affiliations. 